\title{
In Search of a New (National) Historical Record - the Republic of Belarus of 1991-1994
}

Zarys treści: Końcowy etap funkcjonowania Związku Sowieckiego i tworzenie się w 1991 r. nowej Białorusi charakteryzowały duże zawirowania polityczne. W nowej, postsowieckiej rzeczywistości należało inaczej spojrzeć na własne dzieje. Coraz większą siłę zyskiwała narracja narodowa, podkreślająca znaczenie niezależności państwowej i narodowej, jednak większość społeczeństwa i duże grupy historyków nie widziały potrzeby zrywania z dziedzictwem sowieckim. Jednocześnie nowa interpretacja historii nie napotykała na zasadniczy opór. Traktowana była przez większość obywateli jako kolejna akcja narzucana odgórnie przez władze, z tą różnicą, iż teraz można ją było znacznie łatwiej niż w czasach sowieckich krytykować, nie narażając się na represje. Próba budowy nowej wspólnoty opartej o hasła narodowe poniosła klęskę w wyborach $1994 \mathrm{r}$.

Outline of content: The twilight of the Soviet Union and the process of creating a new Belarus in 1991 were marked by major political turbulence. The new post-Soviet reality required that Belarusians look upon their own history from a different perspective. A national narrative which emphasised the significance of state and national independence began to play an increasingly important role. However, the majority of society, along with large groups of historians, did not find it necessary to reject the legacy of the Soviet era. At the same time, they were not particularly resistant to the new interpretation of history. Most citizens perceived it as another campaign imposed by the authorities, with the minor difference that it was now much easier to criticise the idea without risking repression than it had been back in Soviet times. The attempt to build a new society based on a nationalist message failed in the 1994 elections.

Słowa kluczowe: białoruski przekaz historyczny, Republika Białoruś 1991-1994, koncepcja narodowo-państwowa Białorusi, koncepcja ekonomiczno-społeczna Białorusi

Keywords: Belarusian historical record, Republic of Belarus 1991-1994, nation-state concept of Belarus, socio-economic concept of Belarus

The twilight of the Soviet Union and the process of creating a new Belarus in 1991 were marked by major political turbulence. A new world view started to cover the well-known old one. These changes were accompanied by a lowering of living 
standards, which triggered additional political and social perturbation. Belarusians had to take a new look at their own history in the new post-Soviet reality. ${ }^{1}$ They started to discover "blind spots". ${ }^{2}$ A national narrative that emphasised the significance of the state and nation's independence began to play an increasingly important role. People who supported this idea postulated that Belarusian science be made politically neutral, as by then it had served as an ideological support for the communist party. ${ }^{3}$ Belarusian historians were challenged to redefine the former Marxist-Leninist theory. They needed to find a reference point for the new vision of history. ${ }^{4}$ There were two key Belarusian historians of the beginning of the 19th century to whose ideas researchers eagerly referred - Vatslaw Lastowski and Usyevalad Ihnatowski. Their works were copiously reprinted in the independent Belarus. ${ }^{5}$ This was aimed at building a bridge between the time after 1991 and the years of relative freedom and development of Belarusian culture. ${ }^{6}$ The end of the Russian Empire and the beginning of the Soviet state, together with the written heritage produced at that time, was a perfect fit for this role. It was supposed to be an alternative to the hitherto entirely monopolist Soviet historical record.

The end of the Russian Empire and the changes brought by the First World War were also some of the first issues to be addressed in the public discourse of the so-called Gorbachev thaw period. Much attention was especially paid to the circumstances of the establishment of the Belarusian People's Republic. As the political circumstances of 1991 were evolving dynamically it was essential to agree on when the contemporary Belarusian state had actually been established. Belarusians needed urgently to answer the question of whether their statehood had begun on 25 March 1918, when the BPL declared independence, or whether they should perhaps preserve the communist interpretation of history that indicated the night of 1 January 1919 as the date when the Belarusian Soviet Socialist Republic was established. In 1991, when the Soviet Union still formally existed, it was difficult to definitely abandon the view of history that had been presented thus far. For

1 П.Т. Петриков, Очерки новейшей историограбии Беларуси (1990-е - начало 2000-х годов), Минск, 2007, pp. 4, 6; А. Кравцевич, А. Смоленчук, С. Токть, Белорусы: нация Пограничья, Вильнюс, 2011, р. 159.

2 See e.g.: 3apa, 16 January 1992, no. 8.

3 W. Hryckiewicz, "Stan nauki i dydaktyki historii na Białorusi”, Przegląd Wschodni”, 2 (1992/1993), no. 3(7), p. 660.

4 А.П. Минич, Развитие исторической науки Республики Беларусь в 90-е г2. ХХ в. (Формирование новых тенденций) (a self-report study), Гродно, 2009, p. 4-5; А. Ластовский, Специфика исторической памяти в Беларуси: между советским прошлым и национальной перспективой, p. 2, http://www.polit.ru/article/2010/07/19/belorus/ (access: 27 February 2016.)

5 Z.J. Winnicki, Współczesna doktryna i historiografia białoruska (po roku 1989) wobec Polski i polskości, Wrocław, 2003, p. 136.

6 А. Ластоўскі, “Улада і стварэнне гісторыі ў Беларусі: нататкі да канцэптуалізацыі”, in: Беларусь в европейском контексте: актуальные дискуссии о нациостроительстве, eds. О. Шпарага, А. Смоленчук, Вильнюс, 2014, р. 25. 
this reason the discussions concerning the establishment of Belarusian statehood, which took the form of the Belarusian People's Republic, emphasised that it was due to political circumstances that the initiative in question was bound to fail. ${ }^{7}$ Yet, simultaneously, thanks to the ongoing debate in the press, readers became familiar with the names and biographies of Belarusian national activists of the first half of the twentieth century. The press also helped raise awareness of the Stalinist crimes of the late 1930s. Readers could not help but notice that the referenced biographies of Belarusian activists usually ended with BSSR court judgements. ${ }^{8}$ The press keenly described the life of Anton Lutskyevich. ${ }^{9}$ They also referred to the First All-Belarusian Congress organised in December 1917 and pointed out the disruptive role that Bolshevik activists had played in it. Articles describing respective national delegates during the Congress had unambiguous titles such as: "For the Free Motherland" or "We Are Building our Lives, Belarus!"10 During the February Revolution of 1917, the Belarus question was presented in a new light. It was emphasised that the existing interpretation of historical processes should be abolished as it mainly exposed the class factor while it should instead reflect national interests. ${ }^{11}$ In order to make the new historical record more authentic, authors keenly quoted from documents or articles written at that time. ${ }^{12}$

The majority of the people of the Republic of Belarus did not find it necessary to discard Soviet heritage, and favoured preserving the Soviet Union as a state institution. ${ }^{13}$ Historical experience was also said to favour the USSR in the ongoing political debate. Victory over Nazism followed by a quick reconstruction of the republic was possible thanks to the fact that Belarus functioned within the powerful state structure of the USSR - so claimed the proponents of remaining in the union of communist countries. The dynamic economic development of the 1960s and 1970s also provided arguments in favour of preserving the Soviet Union. ${ }^{14}$

The nationalist communities hoped to sever ties with Soviet heritage by referring to pagan Slavic traditions. In 1991, 30 October (the Dziady feast) was declared a public holiday. It was an occasion to commemorate the dead, but it also became

7 У. Казбярук, “Паміж молатам а кавадлам, або Крок наперад, два крокі назад”, Літаратура і мастацтва, 8 March 1991, pp. 13-14.

8 А. Марціновіч, “Памятае не толькі Вольса...”, Літаратура і мастацтва, 11 October 1991, p. 4.

9 Аўтар, “3 жыцця Антона Луцкевіча”, Літаратура і мастацтва, 18 January 1991, p. 13; А. Сідарэвіч, “3 жыцця Антона Луцкевіча. Артыкул другі. Астрожныя запісы”, Літаратура і мастацтва, 25 January 1991, p. 13.

10 “Будуй жа сваё жыццё, беларус!”, Звязда, 20 January 1993, no. 13, p. 3.

11 Г. Саганович, “Историческая политика в постсоветской Беларуси”, Русский вопрос, 2009, no. 2, p. 1, http://www.russkiivopros.com/print.php?id=278, (access: 12 July 2016.)

12 С. Михайлов, “Белая Русь в марте семнадцатого”, Рэспубліка, 12 March 1992, no. 49, p. 4.

13 W. Bocheński, “Między ZSRR a 'łukaszyzmem’. Kształtowanie się systemu społeczno-politycznego Białorusi w latach 1991-1994", in: Zblizanie się Wschodu i Zachodu. Studia - analizy - rozpoznania, eds. P. Kraszewski, T. Miluski, T. Wallas, Poznań, 2002, p. 179.

14 Магілеуская праўда, 1 March 1991, no. 41, pp. 2-3. 
a symbol of the public fight to raise awareness of communist crimes which had been initiated in the $1980 \mathrm{~s}^{15}$

The ongoing debate, which in 1991 was conducted mainly in the press, did not affect the view of history taught in schools. Textbooks described the traditional Soviet interpretation of the history of the BSSR, which emphasised the close ties between Belarus and Russia. ${ }^{16}$ The government had brought about a reform that aimed to introduce the history of Belarus as a separate school subject in secondary schools and a course called 'Belarusian studies' to university curricula, but at that point it was still in the initial stage of implementation. ${ }^{17}$ Due to limited funds, most museums remained virtually unchanged, the only difference being the reduction of information about revolutionary movements in favour of earlier periods. The House-Museum of Adam Mickiewicz in the Town of Navahrudak was an exception: it underwent a major overhaul and was reopened in September 1992. ${ }^{18}$

After the Gennady Yanayev's failed coup attempt in 1991, political changes in Belarus began to accelerate. The demonstrations against the coup d'état organised on 19-21 August in Lenin Square in Minsk strengthened the Belarusian nationalist community. ${ }^{19}$ The number of people who accepted the complete independence of Belarus from Russia was slowly, but steadily growing. In December 1991, only $10 \%$ of population wanted to break off ties with Russia but by February 1992, as many as $30.7 \%$ Belarusians were ready to accept such a step. ${ }^{20}$ Regardless of the deeply ingrained nostalgia for the Soviet Union, the new political circumstances made it possible to write about the dark pages in the contemporary history ever more openly. One of the most controversial issues was familiarising the public with Stalinist crimes. Broadening knowledge of the history and place of crimes committed by the Soviet administration in Kuropaty on the outskirts of Minsk became one of the pillars of the political activity of the Belarusian Popular Front and its community. Wide press coverage of the crimes surrounding the agricultural collectivisation of the 1930s helped raise public awareness of their mass character. ${ }^{21}$

15 A. Łaniewski, “O czym pamięta Białoruś? Katalog białoruskiej pamięci”, in: Pamięć imperiów $w$ Europie Wschodniej. Teoretyczne konteksty i porównania, eds. A. Nowak, M. Wojnar, Kraków, 2015, p. 266.

${ }_{16}$ М. Баранова, Э. Загорульский, Н. Павлова, История БССР. Учебник для 8-9 классов средней школьь, Минск, 1991; Hryckiewicz, Stan nauki, p. 705.

17 J.J. Milewski, "Polsko-białoruska komisja do spraw podręczników historii", Białoruskie Zeszyty Historyczne, 1994, no. 2, p. 130; Z.J. Winnicki, Ideologia państwowa Republiki Białoruś - teoria i praktyka projektu. Analiza politologiczna, Wrocław, 2013, p. 410.

18 Суверенная Беларусь. Иллюстрированная история государства 1991-2008, Минск, 2008, p. 57.

19 T. Gawin, Polskie odrodzenie na Białorusi 1988-2005, Białystok, 2010, pp. 139-141.

${ }^{20}$ R. Radzik, "Formowanie się nowoczesnej Białoruskości w XX stuleciu”, in: Białoruś w XX stuleciu w kręgu kultury i polityki, ed. D. Michaluk, Toruń, 2007, p. 170.

21 "Мужыкі і бабы, або аб тым, як з дапамогаю кулака выпрамлялася партыйная лінія ў сялянскім пытанні", Беларусь, 1991, по. 7 . 
In 1992, the Institute of History at the National Academy of Sciences of Belarus published Aleksander Wróblewski and Tatsyana Prots'ka's work on the repressions against Belarusian peasants in 1929-1934. ${ }^{22}$ The lifting of censorship not only made it possible to discover previously unknown parts of history, but also allowed authors to point to different aspects of well-known events or dates. They used this opportunity in 1992 by publishing an article on the occasion of the anniversary of the seizing of West Belarus in September 1939. The article did not deny that Belarus was divided into Western and Eastern parts but it brought the crimes that accompanied the division to the public's attention. The Polish point of view on those events was also taken into account to a greater degree than previously. The article also mentioned mass deportations and the execution of Polish army officers in Katyn, Russia. It was illustrated with, inter alia, a photograph of a joint German and Russian army parade which took place on 22 September 1939 in Brest-on-theBug. ${ }^{23}$ The public began to recognise the need to individualise the memory of war. The national nature of the celebration of the victory over Nazi Germany did not necessarily exclude other, alternative ways to commemorate respective individuals.

However, comprehensive coverage of historical events that would incline readers to ponder the country's history did not predominate in the press. The descriptions of Stalinist crimes were often sensational. Stalin was compared to Hitler and journalists tried to find common features in both tyrants. ${ }^{24}$ Biographies of other high ranking party officials were also riddled with trivia. They focused mainly on cases of embezzlement. It was a very common and, indeed, convenient way to popularise history. The sensational nature of the message relieved society of having to come to grips with its history. As a result, high ranking party officials remained mere historical figures and their offences did not provoke emotions or deep reflection. Belarusian society was unprepared for independence ${ }^{25}$ and as such it was even less capable of redefining the existing vision of history. Despite ongoing debates about communist crimes, the general public was unwilling to admit their mass character. This step would greatly undermine the pillars on which the Soviet Union was founded, as well as the contemporary independent Belarusian state which emerged from it. The change in awareness was in fact limited to a group of intellectuals in larger cities. It did not reach rural areas and small towns where the constantly deteriorating economic situation was much more important.

22 А. Врублевский, Т. Протько, Из истории репрессий. Против белорусского крестьянства 1929-1934 г2., Минск, 1992.

23 А. Хацкевич, “Сентябрь 1939 года...”, Рэспубліка, 17 September 1992, no. 178, p. 5.

24 В. Колесников, “Путь к тирании. Страницы биографии Гитлера и Сталина”, Рэспубліка, 23 June 1992, no. 117, p. 7.

25 R. Radzik, Białorusini - między Wschodem a Zachodem, Lublin, 2012, p. 146. According to a survey carried out in 1991, only $24 \%$ of ethnic Belarusians defined themselves as BSSR citizens while as many as $69 \%$ saw themselves primarily as citizens of the Soviet Union. This was the highest proportion within all former USSR nations who had their own republics. 
The new national flag and emblem were perceived as merely empty political gestures, associated with increasing poverty rather than a widely accepted change. ${ }^{26}$ Most of the citizens had been brought up in Russian culture and opposed the introduction of the Belarusian language into state administration.

In these socio-economic circumstances, it was therefore understandable that the newly revised description of history did not convince the general public, although it was strongly promoted. The rejection of the existing view focusing on the October Revolution and the Great Patriotic War, coupled with attempts to shift the focus onto descriptions of the Grand Duchy of Lithuania, did not appear very convincing. The history of the Grand Duchy of Lithuania until the Perestroika was unknown not only to society at large, but also to most professional historians. Alyaksandr Krawtsevich wrote: "The political history of the GDL had been a taboo to Belarusian Soviet historians. The process of constructing that particular state was officially deemed a Lithuanian issue". ${ }^{27}$

History based on stories of knights, nobility, dukes and kings was interesting and attractive, but it was not particularly useful for building a new political community. It could not stand comparison with recent history, which aroused much stronger emotions. As the nationalist community did not want to come to grips with the communist era, they decided to marginalise recent events in their historical record, giving preference to the period between the 14th and 17th centuries. The period, which thus far had been nothing more than a matter for school textbooks, was now supposed to become the basis of a new, revised and nationalist vision of history which was to build the new Belarusian identity. In attempts to break away from Russian influence, historians began to promote the myth of the Belarusian Golden Age of the 17th century by referring to research from the turn of the 19 th to the 20 th century. ${ }^{28}$

Mikola Yermalovich's works of the 1980s and 1990s have significantly contributed to promoting the Belarusian character of the Grand Duchy of Lithuania. ${ }^{29}$ He claimed that:

The feudal lords of Navahrudak made the establishment of the GDL possible. It was they who invited the Lithuanian Duke Mindaugas, a renegade who was defeated in a fratricidal fight and forced to flee to Navahrudak [...] As soon as he received financial and military

26 O. Łatyszonek, E. Mironowicz, Historia Białorusi, Białystok [n.d.], p. 288. In September 1991, the Supreme Council of Belarus changed the national symbols.

27 A. Krawcewicz, Powstanie Wielkiego Księstwa Litewskiego, Białystok, 2003, p. 55.

${ }^{28}$ N. Bekus, "Naród białoruski jako idea i kategoria praktyki społecznej. Paradoksy rozwoju postkomunistycznego", in: Tożsamości zbiorowe Białorusinów, ed. R. Radzik, Lublin, 2012, p. 343; Г. Сагановіч, “Змена міфаў беларускай гісторыі як змена палітычных эпох”, in: Беларусь на авансиэне Еурразіі. Паміж Масквой і Кіевам, еd. К. Колб, Варшава, 2014, pp. 50-51.

29 Seе е.g.: М. Ермаловіч, Па слядах аднаго міфба, Менск, 1991; id., Старажытная Беларусь. Віленскі перыяд, Мінск 1994; P. Rudkouski, Białoruska idea narodowa w XXI wieku, Lublin, 2008, p. 14. 
support from the people of Navahrudak, Mindaugas conquered Lithuania - the enclave of the Baltic population on the Belarusian lands - and subjugated it to himself, i.e. to the land of Navahrudak. A historian must conclude: the GDL had been a Belarusian state from its very beginning. ${ }^{30}$

Although this concept was criticised by Lithuanian, Polish and even some Belarusian historians, it was nevertheless useful for redefining the existing historical descriptions in the political reality of Belarus after 1991. "The declaration of independence of Belarus", Krawtsevich wrote, "required that Belarusian historical science shape its own concept of national history. The GDL should undoubtedly play a significant role in this concept as the state in which the Belarusian nation developed". ${ }^{31}$

Yet, in fact, the new heroes from the period of the Grand Duchy of Lithuania could not simply replace the partisans, the soldiers of the Great Patriotic War or the heroic figures of peacetime, i.e. the founders of the communist state..$^{32}$ It was very difficult for the general public, attached as they were to the Soviet vision of history, to make that leap. ${ }^{33}$ However, in order to change the existing patterns, the authorities had to promote this period of history among citizens despite the difficulties. Articles describing the Grand Duchy of Lithuania and the First Polish Republic were published increasingly often. In 1992, the Byelaruska Dumka newspaper published a sizeable article containing a record of discussions among historians entitled "The Belarusian Idea and the Grand Duchy of Lithuania". ${ }^{34}$ Attempts were made to emphasise the Belarusian and Orthodox aspects of the Grand Duchy of Lithuania within its multi-ethnic nature. ${ }^{35}$ As a result, the role of Poles and Lithuanians in that period was marginalised. ${ }^{36}$ The attempts to bring the Belarusian and Lithuanian positions closer to each other in order to come up with a shared vision of history and agree on the significance of the Grand Duchy of Lithuania eventually ended in failure. ${ }^{37}$

${ }^{30}$ Krawcewicz, Powstanie Wielkiego Księstwa Litewskiego, pp. 55-56.

31 Ibid., p. 57.

32 Нама Ніва, 1992, no. 6, p. 2.

33 А. Ластоўскі, Гістарычная памяць у Беларусі: адметнасиі і праблемы, pp. 13, http://old. belcollegium.org/lekcyji/litaratura/lastouski_01.htm (access: 27 February 2016).

34 Т. Якаўлева, “Беларуская ідэя і Вялікае Княства Літоўскае”, Беларуская думка, 1992, по. 10, pp. $62-72$.

35 T. Kruczkowski, H. Wasiuk, "Historia Polski czasów WKL i Rzeczypospolitej w białoruskim czasopiśmiennictwie historycznym końca lat 80-tych - początku 90-tych XX w.", in: Polsko-białoruskie związki językowe, literackie, historyczne i kulturowe. Materiały VI Międzynarodowej Konferencji Naukowej 'Droga ku wzajemności', Grodno-Nowogródek 25-27 IX 1998, ed. M. Kondratiuk, Grodno, 1999, p. 132.

36 М. Ткачоў, Г. Марчук, “Князь Давыдко”, Рэспубліка, 14 July 1992, no. 132, p. 7; П. Раманчук, “Залаты час Льва Сапеги”, Рэспубліка, 25 July 1992, no. 179, p. 4.

37 A. Krawcewicz, "Wielkie Księstwo Litewskie - wizja litewsko-białoruska?", in: Dialog kultur pamięci w regionie ULB, eds. A. Nikžentaitis, M. Kopczyński, Warszawa, 2014, p. 82. 
The eighth of September, which commemorates the victorious battle of Orsha in 1514 fought during the Muscovite-Lithuanian war, became a symbolic date in the process of these changes. ${ }^{38}$ On the anniversary on 8 September 1992, Belarusian officers took a symbolic oath of allegiance to the new Belarusian state on Independence Square in Minsk. ${ }^{39}$ Until 1996, the day was celebrated as the Day of Belarusian Military Glory. ${ }^{40}$ Connecting the contemporary military aspects with the historical battles of Grunwald and Orsha aimed to break away, at least partially, from the Soviet tradition while at the same time strengthening the record of the Grand Duchy of Lithuania. ${ }^{41}$

During the first years after declaring independence, large print runs of albums and richly illustrated brochures were released to popularise the history of the state. ${ }^{42}$ New historical magazines such as Spadchyna (until 1989 known as Pomniki historyi i kultury Byelarusi), Byelaruski histaryczny chasopis, Byelaruskaya minuushchyna or Byelaruski histaryczny ahlad attempted to take another perspective on the national history. The editorial of the first issue of Byelaruskaya minuushchyna included the magazine's programme, which clearly indicated that there was a need to define the national history. ${ }^{43}$ The chairman of the Supreme Council of Belarus, Stanislaw Shushkyevich, expressed the significance of Belarusian national history in a similar tone in his editorial to Byelaruski histaryczny chasopis. ${ }^{44}$ New interpretations of history were also present in long-established press titles which began to publish texts by authors of clearly anti-communist views. The new symbolic language was widely promoted. The most popular postage stamp design depicted the Pahonia coat of arms.$^{45}$ Historical literature was also very popular in that period of political change. It began to be more commonly found in bookshops. Many books from the beginning of the 20th century were reprinted. ${ }^{46}$ However, most of the newly published works did not present a high level of scientific expertise. Their main goal was to nurture national patriotism. The priority of all the actions was to build a new historical record, which would at least partially break away

38 The discussion did not eventually result in a more radical solution to establish Hero Day (Slutski Zbroyni Chin) on the anniversary of the Slutsk Defence Action of 27 November 1920. It was too revolutionary a step both for the elites and the whole of society, which was struggling to sever itself from the Soviet interpretation of history.

39 P. Foligowski, Białoruś. Trudna niepodległość, Wrocław, 1999, p. 55.

${ }^{40}$ Łaniewski, O czym pamięta Białoruś?, p. 272.

${ }^{41}$ E. Temper, "Mity założycielskie Białorusi. Wielkie Księstwo Litewskie kontra Republika Partyzantów”, in: Dialog kultur pamięci, p. 129.

${ }^{42}$ S. Aleksandrowicz, "Jak pisano historię Białorusi w XX wieku?", in: Białoruś w XX stuleciu, p. 51.

43 “Ведаць гісторыю - бачыць будучыню”, Беларуская мінуўшчына, 1993, no. 1, pp. 3-4.

${ }^{44}$ С. Шушкевіч, “Калектыву “Беларускага гістарычнага часопіса”, Беларускі гістарычны uaconic, 1993, no. 1, p. 3.

45 www.belpost.by/eng/stamps/stamp-catalogue/1993/ (access: 16 June 2016).

46 See e.g.: У. Ігнатоўскі, Кароткі нарыс гісторы Беларусі, Мінск, 1992; А. Цьвікевіч, 'Западноруссизм. Нарысы з гісторыі грамадзкай мысьлі на Беларусі ў ХІХ і начатку ХХ в., Менск, 1993; М. Доўнар-Запольскі, Гісторыя Беларусі, Мінск, 1994. 
from the existing Soviet vision. Among such works, one deserves special attention: "100 Questions and Answers on the History of Belarus", which was a very popular publication in the first years of independence. It described the Grand Duchy of Lithuania under Vytautas the Great as the most important country in Europe at that time, or even referred to it as the Belarusian empire. Breaking off with the previously adopted Russian view of history, Belarusians were building their own vision of the past, which was often romantic and heavily imbued with patriotism. ${ }^{47}$ Later, it was referred to as the nation-state concept in scholarly literature. ${ }^{48}$ It was characterised by its limitation of the scope of history mainly to the Belarusian nation and the distance it kept from the scientific achievements of neighbouring countries. At that time, popular opinion in the nationalist community had it that before they could start a polemic with Polish, Lithuanian or Russian academics, they had to create their own, Belarusian concept of history. ${ }^{49}$ Therefore, the priority was to emphasise Belarusian history by evidently marginalising the history of other nations, even very large and important ones such as the Jews. The Holocaust came to be recognised as a separate matter in the history of the Great Patriotic War only at the beginning of the 1990s. ${ }^{50}$

The titles of the scientific conferences organised in the early 1990s, which were aimed at providing at least partially-new interpretations of history, also expressed the need to change the directions of research: 1990, Hrodna - "Vytautas the Great and His Age"; 1991, Hrodna - "The Culture of the Peoples of the Grand Duchy of Lithuania and Belarus throughout the 18th and in the Beginning of the 19th Century"; 1992, Minsk - "Belarus as part of the Grand Duchy of Lithuania"; 1992, Maladzyechna - "Formation and Development of the Belarusian National Identity"; 1993, Brest - "Belarusian-Polish Social, Political, Cultural and Educational Coexistence". ${ }^{51}$ The increased number of publications on the Great Duchy of Lithuania resulted in increased civic interest in this period of history. ${ }^{52}$

A new idea emerged to renovate castles and palaces. The fortress in Mira, considered to be a model example of architecture from the period of the Grand Duchy of Lithuania, was now planned to be renovated. Overshadowed by the nearby castle of Nyasvizh, the Mira fortress did not play a significant role in the

47 See more: 100 пытанняў а адказаў з гісторыі Беларусі, eds. І. Саверчанка, 3. Санько, Мінск, 1994; A. Smalanczuk, "Problemy rozwoju białoruskiej historiografii postsowieckiej albo nauka pod 'jarzmem sowieckości”', Studia Białorutenistyczne, 2011, no. 5, p. 96.

48 Петриков, Очерки новейтей историографии, р. 28.

49 A. Gil, W cieniu przeszłości. Stosunki polsko-ukraińskie i polsko-białoruskie - stan obecny i perspektywy, Lublin, 2010, p. 29.

${ }^{50}$ S. Nowikow, "Historiografia współczesnej Białorusi o Holocauście”, in: Świat niepożegnany. Żydzi na dawnych ziemiach wschodnich Rzeczypospolitej w XVIII-XX wieku, ed. K. Jasiewicz, Warszawa, 2005, p. 934.

51 Winnicki, Wspótczesna doktryna, p. 26.

52 Р. Лінднэр, Гісторыкі і ўлада. Нацыятворчы працэс і гістарычная палітыка у Беларусі XIX-XX cm., Мінск, 2005, р. 468. 
history of the First Polish Republic. As no major political events had taken place there, it was considered a potentially suitable symbol of the new Belarusian age. ${ }^{53}$ However, there were not sufficient funds for such large-scale actions. The country's economic potential did not match the ideological goals of the new authorities. They could promote the concept of the medieval and modern Belarus as the unadulterated historical archetype of the Belarusian state, but it was impossible to easily erase the communist times while the monuments of those periods of history were still crumbling. ${ }^{54}$ Most palaces and castles were dilapidated or, at best, had been turned into makeshift hospitals, schools or offices for collective farms. After many years of communist rule and ongoing indoctrination, the local population did not feel attached to the remnants of the "time of exploitation". They did not find it necessary to restore the estates of the aristocracy to their pristine beauty.

The government's objectives were not met with enthusiasm by citizens who were trying to get their bearings in a deteriorating economic situation. They did not oppose the new interpretation of history, but their attitude to it was hardly enthusiastic. Most Belarusians treated it as yet another initiative imposed by the authorities, with the minor difference that they could now criticise the idea without running the risk of repression. The increasing promotion of the Belarusian language in the social space was met with reserve or even anxiety. ${ }^{55}$ People protested against replacing Russian with Belarusian in schools. ${ }^{56}$ At a time of serious economic downturn, the newly constructed vision of the world was viewed in opposition to fond memories of Soviet times. Nostalgia for the Soviet Union and everything it represented was becoming ever more common. ${ }^{57}$ Quoting Branislaw Tarashkyevich's words on the need to be conscious about the nation's education on the hundredth anniversary of his birth could not have been particularly helpful when at the same time teachers were protesting and calling for improved work conditions. ${ }^{58}$ Kastus Kalinowski's words: "The nation is not to serve the state, but the state is to serve the nation", which the Respublika newspaper used as its watchword, did not sound convincing either. For Belarusian society, it had nothing to do with reality. For them, all that was best had ended with the signing of the Belavezha Accords dissolving the Soviet Union. The pride of being

${ }^{53}$ W. Śleszyński, Kresy Wschodnie czyli Białoruś Zachodnia. Historia, współczesność, pamięć, Łomianki, 2013, pp. 20-23.

${ }_{54}$ М. Багадзя, “Гальшанскі замак”, Беларусь, 1991, no. 2, p. 16.

55 T. Browarek, "Struktura narodowościowa i społeczna Białorusi", in: Białoruś w stosunkach międzynarodowych, ed. I. Topolski, Lublin, 2009, p. 81.

56 N. Mieczkowska, "Stulecie białoruskiego odrodzenia narodowego. Główne wydarzenia i trendy w historii samoświadomości językowej i sytuacji językowej na Białorusi”, in: Tożsamości zbiorowe Białorusinów, p. 136.

57 S. Aleksijewicz, Czarnobylska modlitwa. Kronika przyszłości, Wołowiec, 2012, p. 236-238.

58 М. Стэльмак, “Адгукніцеся, беларускія сэрцы! Аб сённяшнім і мінулым напярэдадні 100-гадовага юбілею Браніслава Тарашкевіча”, Рэспубліка, 18 January 1992, no. 11, p. 5. 
a citizen of the great Soviet empire could not be replaced by a reproduction of a 1903 map depicting the boundaries of the Belarusian ethnos as including Vilnius and Białystok. ${ }^{59}$ It was an attempt to rebuild a sense of belonging while a large part of the Belarusian society was unable to come to terms with having lost their previous country, to which they were strongly attached and of which they were proud.

Nostalgia for the 'good old days' of the USSR was common. ${ }^{60}$ People who had grown up in the Soviet era found it difficult to come to terms with the historical record which banished Vladimir Lenin's ideas and the October Revolution from the public space. They protested against the idea of removing Lenin's monuments or changing street names. ${ }^{61}$ In Homel, attempts to change street names featuring Lenin or Karl Marx were regarded with puzzlement and surprise. ${ }^{62}$ The centrist press warned against leaving behind the role that the Great Patriotic War had played in the Belarusian history. They called for preserving the memory of its victims. An article entitled "So Who Are We?" published by Respublika clearly indicated that the wartime memory should not be erased from the public history of the people of Belarus. ${ }^{63}$ The article criticised the fact that nobody maintained the monuments commemorating the heroes and victims of the Great Patriotic War. The reason that the monuments were not properly cared for was the state's financial troubles and the attempt to break away from the old myth of the Patriotic War. The Brest Fortress museum began to grow over with weeds. ${ }^{64}$ This kind of attitude towards former sacred places of Soviet heritage was commonly criticised. Articles in Bielaruska Dumka lambasted the abandoning of the recently common view of the past. By way of example, they mentioned the communist deputies who became diligent propagators of new ideas in the new political situation. By making comparisons, the authors indicated that the rapid changes resembled the purges from the 1930s or the Chinese Cultural Revolution, rather than evolutionary development. ${ }^{65}$ Some members of the Supreme Council of Belarus also adopted this critical approach. Alexandr Lukashenka, who later became President of the Republic of Belarus, was one of them. ${ }^{66}$ Although he was more interested

59 А. Саламонаў, “Якой ты была, Беларусь мая? Ці яшчэ раз пра дзяржаўныя межы”, Беларусь, 1991, no. 9, pp. 32-33.

60 Р. Медведев, Александр Лукашенко. Контуры белорусской модели, Москва, 2010, p. 105.

${ }^{61}$ After 1990, such dilemmas were absent in the former Lithuanian Soviet Republic, where the matter of communist-inherited street names was quickly resolved. See: J. Wołkonowski, "Polityka historyczna Litwy w latach 1990-2010. Aspekt polski”, in: Wspólne czy osobne? Miejsca pamięci narodów Europy Wschodniej, ed. W. Śleszyński, Białystok-Kraków, 2011, pp. 122-126

62 В. Бондаренко, “Ты говоришь дело, но не по делу”, Рэспубліка, 11 Мау 1992, nо. 86, p. 5.

${ }_{63}$ Р. Тохта-Ходжаева, “Мы не манкурты? Так кто же мы?”, Рэспубліка, 20 June 1992, no. 116.

${ }^{64}$ Śleszyński, Kresy Wschodnie, p. 113.

65 В. Божанов, “Если память короткая. Октябрь 1917-го. Август 1991-го. Насколько относительна и правомерна аналогия?”, Беларуская думка, 1991, no. 6, pp. 8-9.

${ }^{66}$ Медведев, Александр Лукашенко, р. 263. 
in society's economic problems rather than political issues, ${ }^{67}$ he was nevertheless able, as early as in 1992, to adeptly sense social attitudes and the increasing nostalgia for Soviet times. ${ }^{68}$

The ongoing changes in the description of history concerned not only the Republic of Belarus - it was characteristic of the whole former Soviet Union. In that period, publications about history were extremely popular and it was said ironically that everyone was a "historian" ${ }^{69}$ The national concept of history was burgeoning ${ }^{70}$ while the Soviet interpretation of history was ever more boldly being put aside. $^{71}$

However, except for radical political groups, the change was not revolutionary. The authorities attempted to introduce the new view of history and socio-political relations gradually, since Belarusian society still did not accept a radical critique of the communist regime. On the following anniversary of the outbreak of the October Revolution, its critical consequences were also presented. However, the image had not been completely discarded. Lenin was still pictured as a great leader and thinker and nobody dared to criticise him openly, as opposed to the case of his successors (Joseph Stalin, Nikita Khrushchev, and Leonid Brezhnev). Both society and most of its elites, which after all came from the top party officials, were not ready to de-Sovietise history. ${ }^{72}$

The search for a vision of history that would be an alternative to the Soviet one provoked new deliberations and historical evaluations. People wondered on whose side Belarusians had been in 1812. The question was posed of whether the whole community was in favour of the tsar, as was depicted in Russian and, later, Soviet literature. After 1991, in the new political reality, the answer was not so simple. Historians began to recognise the complexity of political choices and gradually redefine the existing evaluations. A similar approach was adopted to the events of 1794 and $1830-1831$.

The issue of Belarusian lands was duly emphasised in the newly created historical record. In this interpretation, the Kościuszko and January uprisings were seen as primarily Belarusian upsurges almost exclusively limited to the areas of

67 S. Owsiannik, J. Striełkowa, Władza a społeczeństwo. Białoruś 1991-1998, Warszawa, 1998, pp. 69; S. Pawelski, "Wesoły - smutny kraj. Białoruś pod rządami Aleksandra Łukaszenki”, in: Zbliżanie się Wschodu i Zachodu, p. 166.

${ }^{68}$ Рэспубліка, 26 March 1992, по. 59.

${ }^{69}$ Г. Бордюгов, В. Козлов, История и конъюнктура. Субъективные заметки об истории советского общества, Москва, 1992, рр. 3, 242.

${ }^{70}$ G. Ioffe, "Długotrwałe poszukiwanie białoruskiej tożsamości”, in: Tożsamości zbiorowe Białorusinów, p. 77; Медведев, Александр Лукашенко, pp. 75-76.

71 See: М. Біч, “Аб нацыянальнай канцэпцый гісторыі і гістарычнай адукацыі ў Рэспубліцы Беларусь”, Беларускі гістарычны часопіс, 1993, по. 1, pp. 15-24.

72 А. Ластовский, “Советское прошлое и беларусская культурная память”, in: О десоветизации. Беларусь, начало ХХІ века. Материалы семинара-конференции, г. Шилуте (Литва), 20-24 августа 2007 г., Минск, 2008, pp. 81-82. 
modern-day Belarus. Similarly, the Belarusian background of their leaders (Tadeusz Kościuszko and Romuald Traugutt) was brought to the public's attention. ${ }^{73}$ Great historical events and figures were often presented against the background of the Belarusian national interest. ${ }^{74}$ The opinion that it was impossible to build a truly independent country without discovering all aspects of Belarusian history was becoming increasingly popular. ${ }^{75}$

The growing importance of references to the First Polish Republic, sometimes even contrary to the authors' intentions, naturally proved that Belarusian heritage was connected to Lithuanian and Polish history. Reaching further back in time obviously diminished the role of Russian heritage and displayed the Lithuanian and Polish character of those lands. It was difficult to point to events that could be discussed without explaining the wider context of the political and social circumstances of the First Polish Republic and without considering the views from Krakow, Warsaw or Vilnius. The vast majority of powerful people connected to the areas of the contemporary Belarus strongly identified themselves with the Polish-Lithuanian raison d'état of that time. Prince Janusz Radziwiłł was one of the few great Polish historical figures who were perceived in a negative light. ${ }^{76}$ It was not easy to adapt this figure, which was strongly attached to Lithuanian nationalist rhetoric, to the Belarusian vision of history. Historians did not stop at emphasising the Belarusian character of that era. Instead of the commonly used term 'Vilnius Baroque' denoting the peculiar nature of that period in the Grand Duchy of Lithuania, it was preferable to talk about 'Belarusian Baroque. ${ }^{77}$ The word 'Belarusian' was used enthusiastically to describe events from the Grand Duchy of Lithuania period. ${ }^{78}$ Historians aimed to create an origins myth for their own nation-state. They also distanced themselves from historical links with Russia. They also emphasised that they were "a long-standing, separate nation, different from the Russians, [...] inheritors of the Grand Duchy of Lithuania". ${ }^{79}$ Additionally, by emphasising the history of the Grand Duchy of Lithuania, they also wanted to fight the stereotype of Belarusian society being an entirely peasant community. The role of historical Belarusian elites was to be played by the local landed gentry and nobility.

Belarusian culture's connection to the West was demonstrated by remembering that the Belarusian language, too, used to be written in Latin characters.

73 Winnicki, Współczesna doktryna, p. 322.

74 Р. Лінднер, “Нацыянальныя і ‘прыдворныя’ гісторыкі „лукашэнкаўскай” Беларусі”, Гістарычны Альманах, 4 (2001), pp. 203-204; А. Смалянчук, "Савецкасиь беларускай постсавецкай гістарыяграфii”, in: Sprawy trudne. Z dziejów stosunków polsko-białoruskich w latach 1918-1945. Geneza, konteksty, konsekwencje, Mińsk, 2013, p. 226.

75 М. Касцюк, “За волю, роўнасць, незалежнасць. Да 200-годдзя паўстання ў Польшчы, на Беларусі і ў Літве”, Беларуская думка, 1994, no. 7, p. 71.

76 М. Багадзяж, “Мяцежны гетман”, Звязда, 23 January 1993, no. 14, p. 3.

77 “Белорусское барокко”, Советская Белоруссия, 11 June 1994, no. 121-122.

78 Петриков, Очерки новейшей историографии, р. 9.

79 Ioffe, Długotrwałe poszukiwanie, p. 63. 
There was the urgent need to build a national intelligentsia, which was indispensable for the development of the independent state..$^{80}$ The relation between having a national culture and a society's future was duly emphasised. ${ }^{81}$ On the fourth anniversary of the declaration of independence of 27 July 1990, the Respublika newspaper printed a photograph showing the moment the previous Soviet emblem was replaced with Pahonia, the new national coat of arms. ${ }^{82}$ The view of the history of Belarus was now not as simple as in the communist period. The press did not always present the biographies of Belarusians following Soviet-era patterns (e.g. of partisans or Red Army officers). It was more common to present the complicated vicissitudes of Belarusians, scattered around the world, or serving in German auxiliary forces or the Polish Second Corps. ${ }^{83}$ The old vision of the world had been undermined and nothing was obvious anymore. People once perceived as traitors now became heroes of contemporary historical and political narratives. The Belarusian history created by emigrants was now reaching the general public. The history created within it was described with an explicitly national (nationalist) perspective.

In 1993, the concept of the Belarusian national school was created. It aimed to eliminate Soviet ideology from the education process. ${ }^{84}$ New textbooks were edited and published.$^{85}$ For the school year of 1993/1994, twenty new history textbooks were written in Belarusian. According to Hienadz' Sahanowich, it was in those books that "for the first time in Belarus, history was considered not from the social class standpoint, but from the national point of view [...]. The approach to the Belarusian history proposed in the new textbooks differed radically from the traditional Soviet one, which annoyed the supporters of the old regime". ${ }^{86}$ Textbooks for years 4, 6 and 11 were titled respectively: "My Motherland - Belarus", "The History of Belarus in the Middle Ages" and "General (World) History". ${ }^{87}$ According to one of the then Polish members of the Polish-Belarusian Textbook Commission, the books were prepared correctly. They presented the common heritage of the First Polish Republic. The year 9 textbook turned out to be the most controversial

80 У. Філякоў, “'Падымайся з нізін, сакаліна сям'я...' Пра станаўленне нацыянальнай самасвядомасці беларусаў”, Беларуская думка, 1993, по. 2, р. 60.

81 Беларуская думка, 1993, no. 10, p. 12.

82 Прэзідыум Вярхоўнага Савета Рэспублікі Беларусь, Са святам вас, суайчыннікі, з Днём незалежнасці!, Рэспубліка, 26 July 1994, no. 144, p. 1 (photo by В. Стрелковский).

83 “Усё вяртаецца на кругі свае", Беларусь, 1993, nо. 6, pp. 14-15.

${ }^{84}$ Кравцевич, Смоленчук, Токть, Белорусь:: нация Пограничья, р. 164.

85 T. Mackiewicz, "Powrót Białorusi do europejskiej przestrzeni kulturowej. Rola edukacji", in: Raport o stanie kultury niezależnej i NGO w Białorusi, eds. T. Arcimowicz, A. Klinau, Lublin, 2011, p. 211; А. Смалянчук, “Радкевіч versus Каліноўскі?”, Ното Historicus, 2008, p. 374.

${ }^{86}$ H. Sahanowicz, "Wojna z białoruską historią", in: Tematy polsko-białoruskie. Historia. Literatura. Edukacja, ed. R. Traba, Olsztyn, 2003, pp. 186-187.

87 В. Кушнер, “Гістарычная адукацыя і палітыка”, Беларускі гістарычны часопіс, 1996, no. 4, p. 6. 
as it described recent history, with numerous Soviet influences. It "is visible even when the authors oppose the existing stereotypes, as while mentioning the terror in West Belarus (towards Belarusians) they add that the Soviet authorities in the BSSR repressed Belarusians equally harshly. In fact, in the BSSR the terror was much more terrifying and took the form of a genocide, an eloquent example of which is what happened in Kuropaty" ${ }^{88}$ In comparison with Soviet textbooks, the new ones were significantly more appreciative of the Grand Duchy of Lithuania period. They especially pointed to the Belarusian character of that state. ${ }^{89}$ In general, the textbooks were well received by the Polish experts who worked with the joint Polish-Belarusian Textbook Committee..$^{90}$

The Institute of History of the Belarusian Academy of Sciences in Minsk prepared a two-volume work entitled "A Brief Outline of the History of Belarus", which marked the culmination of the new period of research on Belarusian history. The first volume was published in 1994 and the second in 1995. The result of this teamwork, led by Mikhail Kastsyuk, was largely opposed to the Soviet concept of the history of Belarus. The image presented in the publication aimed above all to present the Belarusian character of historical changes. ${ }^{91}$ The period of the Second Polish Republic was described according to the patterns adopted in Soviet times, which showed the Belarusians' fight against the Polish oppression, the difference being that the class struggle had been replaced with the "national liberation movement". ${ }^{92}$ The new narrative did not significantly change the description of history itself but the leaders' intentions were presented differently - now they were not only communist party activists but also activists who accepted nationalist ideas. The authors realised that while they emphasised the nationalist message, they could not categorically deny the existing vision of history. In order for the citizens to accept this view, it had to evolve gradually. That is why the next anniversary of the declaration of independence on 25 March 1993 was illustrated by the press with three photographs that symbolically demonstrated the evolution of views. The first picture depicted soldiers marching during the Revolution; in the second, Red Army soldiers were going to battle during the Great Patriotic War, while the third photograph showed a parade of soldiers received by the current authorities who were standing under the white-red-white flag. ${ }^{93}$ The first two volumes of The Encyclopaedia of the History of Belarus were also symbolic as they clearly

\footnotetext{
${ }^{88}$ Milewski, Polsko-białoruska komisja, p. 130.

89 A. Dziarnowicz, “'Poszukiwanie Ojczyzny'. Dyskurs na temat Wielkiego Księstwa Litewskiego we współczesnym społeczeństwie białoruskim”, in: Dialog kultur pamięci, pp. 138-143.

90 J.J. Milewski, "Polsko-białoruskie komisje podręcznikowe”, Zeszyty Historyczne, 1998, no. 123, p. 216.

91 Петриков, Очерки новейшей историографии, р. 53.

92 М. Касцюк, І. Ігнаценка, У. Вышынскі (і інш.), Нарысы гісторыі Беларусі, ч. 2, Мінск 1995, p. 223.

93 Рэспубліка, 23 February 1994, nо. 36-37.
} 
exhibited the nationalist vision of history. ${ }^{94}$ The general idea of the new publication is best formulated by the following excerpt from the first volume's foreword:

This is the first encyclopaedia in the history of our motherland, the authors of which attempt best to illustrate the centuries-long path that Belarusians have travelled, starting with the distant past up to the present day, based on the latest achievements of science and considering the inseparable relation with the historical process in Europe. It sheds light on all of the significant events that took place on the territory of Belarus. Its pages include information about political, social and wartime phenomena and events, about the administrative and territorial divisions, and about the state of the economy, science and engineering at different stages of history. [...] The Encyclopaedia reflects the history of Poles, Lithuanians, Russians, Jews, Tatars and representatives of other nations who have lived in Belarus for ages and their contributions to Belarusian and European culture. Is also sheds light on the life of the Belarusian diaspora at various points in history. ${ }^{95}$

Scientists faced an enormous challenge which was very difficult to meet: to break away from Marxist methodology. The existing higher education system served the ideological needs of the communist party instead of shaping independent researchers. ${ }^{96}$ From the scientific point of view, most historians supporting the nationalist option did not know how to stop using Soviet methodology and research tools. They argued about the historical message and its various manifestations instead of searching for new ways of conducting historical research. ${ }^{97}$ Breaking away from the view of Belarusian history as a part of the history of Russian or Soviet lands was undoubtedly a great success. The history of Belarus became an academic discipline in its own right. ${ }^{98}$

In the following years, society became familiar with difficult topics, mainly relating to Stalinist crimes, and always by turning the matter into sensational stories. The articles published by Respublika on the one hand informed citizens about events that had been glossed over for years. On the other hand, the articles failed to grapple with difficult historical events, as this could have been unacceptable to a sizeable section of the Belarusian society. The editors believed that Belarusians had to first become familiar with and take on board that knowledge before the authorities could build a viable political message. In an editorial note, they were wondering how they should deal with the information that Stalin had killed more Soviet citizens than Hitler. The authors emphasised that it was difficult to acknowledge all those facts and still refer to the achievements of that Soviet leader in the

94 Петриков, Очерки новейщей историографии, р. 7.

95 Aleksandrowicz, Jak pisano historię Białorusi, pp. 50-51.

96 P.A. Szuplak, "Problemy edukacji historycznej w szkołach wyższych Republiki Białoruś", in: Polska-Białoruś 1918-1945, ed. W. Balcerak, Warszawa, 1994, pp. 192-193.

97 Z.J. Winnicki, Tematy białorusko-polskie. Antologia, Wrocław, 2010, pp. 167, 171.

98 А. Смалянчук, “Беларуская постсавецкая гістарыяграфія: паміж рэсаветызацыяй і новай карпаратыўнай этыкай”, Arche, 2013, no. 2, p. 259. 
ongoing political debate. Nationalists eagerly used the figure of Stalin to indirectly discredit the whole communist system. In that time of chaos, when the existing world view was collapsing, when it was being proposed to move Lenin's body from his mausoleum to Gorki near Moscow, Belarusians also wanted to create their new view of history. ${ }^{99}$ It was an extremely challenging task. Historical discourse became an important part of the political dispute in a politically and economically unstable time. The main dividing line was between supporters of the new nationalist view and those of the old Soviet world.

The increasing emphasis of the national character of Belarusian history not only meant abandoning the Russian perspective, but also made it necessary to come up with a new way to view relations with Poland and Poles. The main subject of the dispute remained the question of whether or not Belarusian citizens who declared their nationality as Polish should in fact be called Poles. Both nationalist and post-Soviet circles firmly supported the idea that they should be regarded as Polonised Belarusians. ${ }^{100}$ Both parties also viewed the role of the Catholic Church in a negative light. Using religious categories to determine one's nationality was considered wrong. ${ }^{101}$

The relations between Poland and Belarus were regarded as positive. There were no major conflicts, nor were the current or historical issues considered problematic. Initially, there had been some misunderstandings regarding the historical identity of the Białystok region (in unofficial discussions, Belarusians wanted to refer to the arrangements of the People's Assembly of Western Belarus of 1939 in spite of the decisions taken in 1944 concerning the borders, which was contested by Polish diplomats). However, neither party ventured to question the existing border. On 23 June 1992 in Warsaw, the countries signed the Treaty of Good Neighbourship and Friendly Cooperation between the Republic of Poland and the Republic of Belarus, which confirmed the good relations between the two states. ${ }^{102}$

Belarusians described Polish contemporary history in accordance with the new Polish interpretation. It was marked by the years of the most important events of the Polish People's Republic period which epitomised society's rebellious attitude toward the authorities, i.e. 1956, 1968, 1970, 1976 and $1980 .{ }^{103}$ The two countries were unable to reach a consensus as to the events of 17 September 1939. In their new rhetoric, Belarusians emphasised that those events contrib-

99 “Ленина выселили из Кремля”, Рэспубліка, 9 September 1994, no. 175, p. 7.

100 K. Frąckiewicz, "Białoruska opozycja narodowa a problematyka 'odrodzenia' polskości w BSRR-RB”, in: Polska mniejszość narodowa na Białorusi 1998-2009. Ocena minionego dwudziestolecia, eds. Z.J. Winnicki, T. Gawin, Białystok, 2009, p. 171.

101 Ioffe, Długotrwałe poszukiwanie, p. 70.

102 H. Głogowska, Stosunki polsko-białoruskie w XX wieku. Od Imperium Rosyjskiego do Unii Europejskiej, Białystok, 2012, pp. 394-400.

103 С. Рашэтнікаў, В. Бенькоўскі, “Прагнастычны праект. Беларусь - Польшча”, Беларусь, 1993, no. 2, p. 5. 
uted to the unification of Western and Eastern Belarus, but at the same time they began to write more about the behind-the-scenes decisions of that time, such as the Molotov-Ribbentrop Pact or the crimes committed by the NKVD. ${ }^{104}$ In 1992, on the tide of change, Grodnienska Prawda did not give much publicity to the anniversary of 17 September. ${ }^{105}$ While creating descriptions of those events in the following years, authors also pointed to the alliance between Stalin and Hitler which functioned at that time. However, they firmly rejected the possibility of apportioning Stalin blame for the outbreak of the Second World War on a par with that ascribed to Hitler. On 22 June 1994, Sovietska Byelorusia published an article in which the author tried to convince readers that the Wehrmacht would have attacked Poland anyway in September 1939, regardless of whether the German-Soviet Non-aggression Pact had been signed; ${ }^{106}$ it was also emphasised that Germany could have attacked the Soviet Union much earlier than in June 1941 had it not been for the Pact. Although the Belarusian interpretation of the 1939 and 1941 events included new information, it could not definitely disregard the Soviet historical message. ${ }^{107}$ Neither researchers nor society were ready for such a far-reaching re-interpretation of the beginning of the war. Nostalgia for the Soviet vision of history was particularly noticeable in the descriptions of the Great Patriotic War. The living veterans and their families were unable to come to terms with diminishing the role of the Red Army and with relative evaluations of the attitudes of Belarusian collaborators. The Polish Home Army was considered hostile towards the Belarusian interest. Its members were effectively denied veteran rights. The Polish military units of World War II were perceived negatively by both post-Soviet and nationalist circles. ${ }^{108}$

Although the state relations were good, Belarusians still feared Polish expansion. Poland was considered a threat to Belarusian heritage, especially in the new, nationalist vision of history. This was noticeable in the descriptions of both distant and recent past. Attention was paid to the hostile policy of interwar Poland towards the Belarusian minority. From time to time the Belarusian press reported about the minority being harassed in Poland. Journalists emphasised the instances of the number of Belarusian schools in the Białostockie voivodeship being reduced and the emergence of anti-Belarusian wall inscriptions in public spaces in order to

104 И. Гришан, “Обретение Родины. 55 лет назад произошло воссоединение белорусских земель”, Советская Белоруссия, 17 September 1994, no. 198-199, pp. $2,5$.

105 Gawin, Polskie odrodzenie, p. 171.

106 И. Гришан, “Ледокол в торосах лжи”, Советская Белоруссия, 22 June 1994, no. 131, pp. 1-2.

107 А. Смалянчук, “Верасень 1939 г. у савецкай і беларускай гістарыяграфіi”, Гістарычны Альманах, 3 (2000), р. 86.

108 See е.g.: В. Ермолович, С. Жумарь, Огнём и мечом. Хроника польского националистического подполья в Белоруссии (1939-1953 г2.), Минск, 1994; І. Крэнь, “Праблемы Арміі Краёвай у беларускай гістарыяграфіi (сярэдзіна 80-х - 90-я гады)”, in: Polsko-białoruskie związi jezzykowe, pp. 159-167. 
substantiate the claim that Poland was persisting in its repressive policy. ${ }^{109}$ Poles living in Belarus also feared the increase of anti-Polish attitudes in Belarusian society. In 1992, Magazyn Polski wrote that "The Belarusian nation is searching for its own identity. Under these circumstances there is a risk that mutual discords and nationalist accents will emerge". ${ }^{110}$ This sort of "article war" in which authors eagerly interpreted the development of the Polish national movement in Belarus, was especially characteristic of the beginning of the Belarusian Popular Front's activities. Tadeusz Gawin, the first leader of the Union of Poles in Belarus, supported rapprochement with the Belarusian nationalist circles. It was mainly on his initiative that relations improved after 1992 and as a result Poles took part in the first Independence Day celebrated on 27 July 1992 in Minsk. The Polish-Belarusian (nationalist) rapprochement also benefited from the strife between independence supporters and conservatives (post-Soviets), who were nostalgic for the Soviet Union. Despite their differences, the activists of the Union of Poles in Belarus took the influential nationalists' side, as the nationalist Belarusian interpretation of history was much closer to them than the Soviet version. It is also noteworthy that Poles in Belarus counted on some concessions regarding education. They expected the authorities to agree to open Polish schools and refrain from inhibiting Polish organisations from developing. ${ }^{111}$

References to a specific heritage played a significant role in polarising opinions, which was important with the prospect of presidential elections in 1994. After the changes that the country had undergone in 1991, the question of which perspective should be used to create the nation's history became topical. National communities were continuously taking decisive actions to create a new national identity. ${ }^{112}$ They consistently attempted to carry out their own historical policy. Supporters of this idea found their views reflected in the Narodna Gazeta, Nasha Niva and other newspapers. The latter in particular framed the new concept of history that emphasised the role and significance of the Belarusian raison d'état. Nasha Niva depicted Belarus as a state that exhibited European features and had its own national history and culture. The Soviet period, especially the time of Stalinist repressions, was described as a dark age in the history of Belarus. ${ }^{13}$

109 М. Ковалев, “Чужие на своей земле”, Советская Белоруссия, 1 October 1994, no. 235.

110 M. Gumienik, "Szermowały hasłami o jednolitym społeczeństwie”, Magazyn Polski, 1992, no. 3-4, p. 42.

111 Gawin, Polskie odrodzenie, pp. 182-187.

112 A. Lastoŭski, "The Genealogy of National Statehood in the Historical Memory of Belarusians", in: Revolt in the Name of Freedom. Forgotten Belarusian Gene?, eds. P. Rudkoŭski, K. Kolb, Warszawa, 2013, p. 137.

113 В. Шаталава, “Нацыянальная ідэя на старонках беларускай прэсы 1991-1994 гг.”, in: Białoruś $w$ XX, pp. 179-188; Т. Островская, “Генеалогия исторической памяти Белорусов в контексте образовательных практик”, Исследование. Bielarusian Institute for Strategic Studies, 20 October 2010, p. 23. 
The historians who represented the nation-state concept created the intellectual backbone of the nationalist option. Mikhas Bich laid the foundations for this concept $^{114}$ and after 1991, the Institute of History at the National Academy of Sciences of Belarus led by Kastsyuk continued to work on this idea. The concept broke off with the existing methodology based on Soviet ideology and stressed the need to carry out a "3 de-" process: "de-ideologisation", "de-politicisation", and "de-partisation" of historical research. ${ }^{115}$ The nation-state idea postulated that although the name of Belarus did not exist in state terminology, Belarusians did have their own states. Those states might not have fulfilled all the nation's dreams but they were political entities created by Belarusians themselves. The Grand Duchy of Lithuania was the most prominent example of this thesis. The Belarusian People's Republic and the Belarusian Soviet Socialist Republic exemplified the complete state-building processes. ${ }^{116}$

According to the nation-state concept, historical research and descriptions were to primarily reflect national interests and stress the ethno-cultural nature of the Belarusian nation. ${ }^{117}$ It aimed to explain the term "Belarus" anew to the citizens as a nation-state area, contrary to the Russian and Soviet interpretations. The history of Belarus derived from the Principality of Polotsk (Prince Vsyaslaw Bryachislavich [the Sorcerer] and Princess Yewfrasinya of Polotsk), to pass to the Grand Duchy of Lithuania period with a particular emphasis on the Belarusian element. ${ }^{118}$ It was said that a negative time in the Grand Duchy of Lithuania started in 1569 with the Union of Lublin, as the local nobility was then rapidly Polonised. ${ }^{119}$ They renounced their cultural heritage in order to multiply their riches. This created a dissonance between the increasingly Polonised nobility and the still Belarusian peasantry. As a result, the country's position was weakened and eventually collapsed.

Academics received this concept with general criticism. Its political opponents accused it of being too nationalist, which in Belarus at the time meant abandoning everything that was Russian (and Soviet in particular). The experts were willing to rewrite history, even with regard to the more distant past, yet this kind of interpretation was difficult to accept for most Belarusian historians, who had been brought up in Soviet schools. They saw the new, polemic historical methodology

\footnotetext{
114 H. Sahanowicz, "Losy białoruskiej historiografii: od sowietyzacji do zachodniorusizmu nowego typu”, Studia Białorutenistyczne, 2009, no. 3, p. 125.

115 Петриков, Очерки новейщей историографии, р. 28; В. Снапковский, "Историческая политика в Беларуси в период перестройки и парламентской республики (1985-1994 гг.)”, Труды факультета международных отношений. Научный сборник, 2014, nо. 5, pp. 65-66.

116 Петриков, Очерки новейшей историографии, р. 31.

117 А. Казакевіч, “Канцэпцыі (ідэі) беларускай нацыі ў перыяд незалежнасці 1990-2009”, Палітычная сфера, 2010, no. 14, pp. 9-11.

118 Лінднэр, Гісторыкі і уллада, pp. 450-459.

119 Radzik, Białorusini - między Wschodem a Zachodem, p. 164.
} 
as an attack not only on the existing historical record but also on the whole view of the world. ${ }^{120}$ A work on the Russo-Polish War of 1654-1667 by Sahanowich was a good example of the new approach to the history of the Belarusian lands. The description of those events showed Russians in a bad light. Belarus lost over a half of its people during that time due to slaughters, deportation deep into Russia, epidemics and famine caused by military actions. ${ }^{121}$ Sahanowich decidedly broke away from the Soviet perceptions of this period in Belarusian history. The opponents of the nation-state view pointed out that some of its supporters went as far as to question the existence of the old Rus' nation saying that it was only an invention of Russian historiography.

The fact that the supporters of the nation-state concept stressed the pro-Western option did not mean that they favoured Polish or Lithuanian historiography. They especially feared that Polish influence could become predominant as regards past historical processes. The fundamental aim of the research was to exhibit Belarusian-ness in every possible element of the past. Researchers did recognise the need to use the achievements of Russian, Soviet, Polish or Lithuanian historiography, but only with a view to building their own, national view of history. Belarusians needed to "write monographs from the Belarusian, not foreign, point of view"122 as Valantsin Hrytskyewich pointed out in his deliberations on the challenges that Belarusian researchers had to face. This was the way to reinforce the belief that Belarusians were a powerful nation it their own right. This belief was to become a pillar in the structure of national unity. However, it simply lead to a stigmatisation of the nation's history. The foreword to Zianon Pazniak's book of 1994 about the Soviet crime in Kuropaty exhibits his messianic role. He wrote:

If we consider the history of Belarus - we will see that it is a history of suffering. Belarusians have been shouldering their penitential cross for over a hundred years - negligence, betrayals, fascism, communism, genocides - and there is still the stigma of the star [...]. Yet we are alive. We, the people of God in a sense. The Great Land. We are going back to our roots. Our hearts do not grow heavy when life gets difficult. Let us not grieve over our suffering. God loves the penitents and those who are patient. Let us rise with the dignity of a nation that loves its cross. Because we are rising from the dead. Our saint and pure white-red-white flag is already flown above us. ${ }^{123}$

Although the proposed nation-state concept was strongly promoted from 1991 to 1994, it hardly broke through to the general public. The stronger and more radical members of the nationalist school of thought articulated it, the less chance it had to really influence people. Many citizens found it difficult to deny

120 Петриков, Очерки новейшей историографии, р. 33.

121 Aleksandrowicz, Jak pisano historię Białorusi, p. 49.

122 Hryckiewicz, Stan nauki, p. 771.

123 Quoted after: Winnicki, Wspótczesna doktryna, p. 18. 
the ideals with which they grew up and identified, even in the new political situation. In order to deny those ideals, they would have to recant their faith that the construction of the communist state was legitimate. For them, the collapse of the Soviet Union with its ensuing changes was the end of their world. The more the new vision of history pushed the traditional Soviet description aside and shed a bad light on it, the more unacceptable it was to the people. Many Belarusians felt that the Belarusianisation of political, social and cultural life was being carried out too aggressively and they did not understand it. Readers were wary of receiving the works of expatriate historians, a great majority of whom descended from the communities that had cooperated with the Nazis in 1941-1944. Their interpretation of Belarusian history was at times much more radical than that of local historians. ${ }^{124}$ Neither Belarusian historians nor society as a whole were prepared to accept the tradition of national emigration. This does not change the fact that the work of Yanka Zaprudnik, originally published in Western Europe in 1993 and afterwards in Belarus in 1996, at one point was one of the most popular books. ${ }^{125}$

Although in 1991-1994 the historical record was largely dominated by nationalist rhetoric, the Soviet interpretation of history has never ultimately been forced out of the Belarusian public space. On the contrary, it grew with the deteriorating economic situation. The historical message marked with Soviet accents existed in the daily press. It did not disappear from Sovietska Bielarusia where it functioned alongside the new, more nationalist vision of history. ${ }^{126}$ Suppressed and pushed aside by the new rhetoric, it was waiting for another opportunity for expression. The nostalgia for the Soviet days was also present. According to a survey carried out in 1993, 51\% of citizens wanted to restore the Soviet Union and only $22 \%$ did not. ${ }^{127}$ The post-Soviet top party officials clearly had difficulty accepting a different vision of history. They found it difficult to identify with the new symbols and historical narrative.

Another idea, the concept of the socio-economic development of the nation, which was based on Marxist-Leninist theory and stood in opposition to the nationstate idea, quite obviously sought inspiration in the historical tradition of the Soviet school of thought. On this premise, the Belarusian state structure was created only after the October Revolution. The concept stressed that it was due to the merits not of the previous state systems but of the nation that Belarusians had preserved their own independent culture which had been formed in specific political and economic circumstances. ${ }^{128}$ Supporters of this idea criticised the nationalist approach to the Grand Duchy of Lithuania that exposed it as a Belarusian product

124 Ibid., p. 98.

125 Я. Запруднік, Беларусь на гістарычных скрыжаваннях, Мінск, 1996.

126 Шаталава, Нацыянальная ідэя, pp. 176-178.

127 M. Riabczuk, “Wschodniosłowiańska 'umma' a problem emancypacji. O 'słabej' tożsamości Ukraińców i Białorusinów”, in: Tożsamości zbiorowe Białorusinów, p. 361.

128 Петриков, Очерки новейшей историографии, р. 41. 
and disregarded its Lithuanian and then Polish nature. They also pointed to the fact that the Orthodox community in that period was in a much more difficult political and economic situation than Catholics. They stressed that the rapidly Polonising landed gentry aimed to dominate the peasant community and, likewise, the goal of the Catholic Church was missionary activity. The socio-economic concept displayed a lack of logic in the attempts to prove the Belarusian background of Prince Mindaugas, who supposedly represented the Belarusian raison d'état. ${ }^{129}$ According to this concept, the situation in the Belarusian lands did not improve until it became part of Russia at the end of the 18th century. Although relations with Russia, especially Soviet-period relations, were described much more critically than they had been under communism, it was still based on the principle derived from the old historical school: the tsar was bad, but Russia was good, or: Stalin was bad, but the Soviet Union was good. The concept stressed close ties to Russian culture and heritage. It was Russia-centred. ${ }^{130}$ Supporters of the socio-economic concept did not agree with most of the interpretations made by the nationalist community, which aimed to undermine the Soviet description of history. They were unable and unwilling to break away from the old view of the world.

In the political reality of 1993 and 1994 it was relatively easy to reconstruct the plain and simple division into the good East and bad West. It began to correspond with political divisions. The socio-economists found it easy to attack the nation-state communities, as many of the latter had Catholic backgrounds, which was popularly identified as a foreign, Western (Polish) culture. Nationalists were accused of hostility towards the Eastern civilisation, represented by the Orthodox Church. The political division shaped in 1991-1994 dominated in the subsequent years of the emerging political dispute.

In 1994, nostalgia for the "good Soviet times" became increasingly visible. ${ }^{131}$ On the 76th anniversary of Pyotr Masherov's birth, Sovietska Belarusia published a photograph showing him sitting in his office with a portrait of Lenin in the background. ${ }^{132}$ It was a reference to the best period in the contemporary history of Belarus and expressed the hope of finding a great statesman of equal stature for the present day. The 70th anniversary of Lenin's death was celebrated in a similar, ceremonial tone with his portrait taking a prominent position. The newspaper also recalled the 1st May anniversary with a tinge of nostalgia and irony. On the background of an old postcard from the Soviet era there was a contemporary caption reading "We had peace, we had jobs, and all we have left is May ...". ${ }^{133}$

129 Ibid., pp. 34-35, 43.

130 A. Kazakiević, "Współczesna białoruska tożsamość historyczna”, in: Tożsamości zbiorowe Białorusinów, p. 248.

131 A. Poczobut, System Białoruś, Gliwice, 2012, p. 64.

132 "13 февраля одному из самых ярких политических деятелей Беларуси Петру Мироновичу Машерову исполнилось бы 76 лет”, Советская Белоруссия, 12 February 1994, no. 32-33.

133 Советская Белоруссия, 7 Мау 1994, nо. 93-94. 
Other newspapers also printed similar pictures criticising the ongoing changes. Respublika published a photograph showing a fragment of a destroyed building with a damaged portrait of Lenin thrown out of the window. ${ }^{134}$

The fight to create a new historical message was exacerbated in 1994 when the presidential campaign entered its final stage. Both nationalist circles and those who referred to the Soviet view of history came to understand that history was an important part of the campaign in helping voters identify with their candidates. The memory of the Great Patriotic War, which in the Soviet era had been one of the key elements of historical policy did not become outdated; quite the contrary, it became even more topical. ${ }^{135}$ The conditions of a political campaign were not conducive to engaging in multi-layered deliberations. The press made simple references to the great victory over Nazism of 1944 and 1945 again, just like in the Soviet Union. The anniversary of 9th May regained its significance. Sovietska Belarusia printed photographs of veterans, old propaganda posters and pictures of cheerful children and youth. ${ }^{136}$ They tried to connect those historical events with the current political situation. Alexandr Lukashenka benefited from this climate most as he skilfully combined the nostalgia for the Soviet Union with the negative view of the current political and economic situation. The authorities also tried to build on those social attitudes. The Belarusian press published occasional texts by Prime Minister Vyacheslaw Kyebich. ${ }^{137}$ Appeals to veterans aimed to recreate the atmosphere of the holiday from Soviet times. They expressed pride at the victory of the whole Belarusian nation.

The result of the first round of the election, in which Alexandr Lukashenka defeated all his opponents, confirmed society's desire to restore the "good Soviet times". ${ }^{138}$ Before the second round, Prime Minister Kyebich continued to use the media to his advantage and got actively involved in patriotic celebrations. ${ }^{139}$ During the second round of the election, both candidates spoke of the Soviet construction of the past and the need to strengthen ties with Russia. ${ }^{140}$ The historical message about the wartime years which was being presented at that time referred directly to the image known from the communist days. Lukashenka turned out to be more credible in his rhetoric. In terms of historical message he offered to return to the

134 Рэспубліка, 21 January 1994, no. 12.

135 Гомельская праўда, 26 March 1994, no. 33.

136 Советская Белоруссия, 7 Мау 1994, по. 93-94, p. 1.

137 В. Кебич, “Дорогие ветераны Великой Отечественной войны!”, Советская Белоруссия, 7 May 1994, no. 93-94, p. 1.

138 E. Mironowicz, Białoruś, Warszawa, 1999, p. 242.

139 “От великой победы к стабильности и согласию. Выступление Председателя Совета Министров Републики Беларусь В.Ф. Кевича на торжественном собрании, посвященном 50-летию освобождения Беларуси от немецко-фашистских захватчиков”, Рэспубліка, 30 June 1994, no. 125, pp. 2-3; М. Гриб, В. Кебич, "Участникам освобождения Беларуси от немецко-фашистских захватчиков”, Советская Белоруссия, 2 July 1994, no. 138, p. 1.

140 Mieczkowska, Stulecie białoruskiego odrodzenia, p. 158. 
simple division between good (communism and the Soviet Union) and bad (Nazism and the Belarusian nationalists who collaborated with the Germans) which were well known from communist times. Simultaneously, he sided with the majority of citizens who identified with and longed for the Soviet Union and its successes.

The attempt to build a new community based on a nationalist message failed in the 1994 elections. Society was unprepared to replace the Soviet class system of values with the national Belarusian one that was proposed after 1991. The efforts made to combine them ended in failure. The "West-Russian" idea created in the 19th century and later modified and Sovietised in the BSSR became a significant element of Belarusian identity. The nationalist circles proved unable to reconstruct it in 1991-1994. Belarusian nationalists lacked the determination to create a new (national) historical message. Despite the formally set goals, the actions they undertook not only faced resistance from post-Soviet top party officials, but they were also rejected by the majority of Belarusian society. The Soviet view of history that had been shaped by generations could not successfully be erased in just a few years.

\section{In Search of a New (National) Historical Record - the Republic of Belarus of 1991-1994}

\section{Abstract}

The final stage of the Soviet Union and the creation in 1991 of a new Belarusian state were characterised by big political whirls. There was the need in a new, post-Soviet reality, for a different look at the nation's own history. Increasingly strong was national narrative, emphasising the importance of political and national independence. Those milieux demanded that Belarusian sciences should be made independent of the party, for thus far they were treated as the ideological resource base for the communist party.

A large part of Belarusians, however, and numerous groups of historians did not see the necessity to break up with Soviet heritage. The majority of citizens of the Belarusian Republic opted for the existence of the Soviet Union as the political entity. A new interpretation of history met neither with any special resistance, nor enthusiasm. It was regarded is as yet another action imposed by the authorities, the only difference being that this time it was possible to criticise it much more easily without the fear of severe reprisals as in the Soviet times.

There was a general feeling of nostalgia for the good, Soviet times. The fight for the construction of a new interpretation of history intensified after 1994, when the presidential campaign entered its final stage. Both the national circles and those appealing to the Soviet version of history understood that historical topics made an important element of the campaign which made it possible for electors to better identify with their candidate.

An attempt to build a new community based on national banners suffered defeat in the elections of 1994. The society was not ready to reject the Soviet-class system of values and replace it with a new national-Belarusian offered after 1991. Neither a symbiosis was created that could combine these two systems. The "West Russian" idea, developed in the nineteenth century, but modified and Sovieticized during the period of Belarusian Soviet Republic, became a strong element of the Belarusian identity, and national circles proved to be unable to weaken it in the years of 1991-1994. 


\section{В поисках нового (национального) исторического повествования - Республика Беларусь 1991-1994}

\section{Аннотация}

Заключительный этап существования Советского Союза и формирование в 1991 году новой Белоруссии характеризовались большими политическими проблемами. В новой, намечающейся постсоветской действительности надо было по-другому посмотреть на собственную историю. Укреплялось национальное повествование, подчеркивающее значение государственной и национальной независимости. Национальные круги выступали за партийную нейтрализацию белорусской науки, которая до сих пор была идеологической базой коммунистической партии.

Однако подавляющая часть общества и большие группы историков не видели необходимости порвать с советским наследством, выступая за оставление Советского Союза как государственного учреждения. Новая интерпретация истории не встретилась с решительным сопротивлением, но и не вызвала особого восторга. Большинство граждан относилось к ней как к очередной акции, навязанной сверху властями, однако с той разницей, что теперь ее можно было гораздо легче раскритиковать, чем в советские времена, не подвергая себя репрессиям.

Ностальгия за хорошими, советскими временами была всеобщей. Борьба за создание исторического повествования усилилась в 1994 году, когда в окончательную фазу спора вступила президентская кампания. Как национальные круги, так и те, обращающиеся к советской картине истории, понимали, что исторические темы являются важным элементом кампании, позволяющим избирателю лучше отождествить себя с конкретным кандидатом.

Попытка создать новое сообщество, опираясь на национальные лозунги, потерпела поражение в выборах 1994 года. Общество не было готово отбросить советско-классовую систему ценностей и поменять ее на национально-белорусскую, предложенную после 1991 года. Не был разработан и своего рода симбиоз, который смог бы совместить обе эти системы ценностей. Образовавшаяся в XIX веке «западнорусская» идея, модифицированная и советизированная в период БССР, стала мощной частью белорусской идентичности, которую не смогли перестроить национальные круги в 1991-1994 гг.

Перевод Агнешка Поспишиль

\section{Bibliography}

\section{Secondary literature}

Aleksandrowicz S., "Jak pisano historię Białorusi w XX wieku?", in: Białoruś w XX stuleciu w kręgu kultury i polityki, ed. D. Michaluk, Toruń, 2007.

Aleksijewicz S., Czarnobylska modlitwa. Kronika przyszłości, Wołowiec, 2012.

Bekus N., "Naród białoruski jako idea i kategoria praktyki społecznej. Paradoksy rozwoju postkomunistycznego", in: Tożsamości zbiorowe Białorusinów, ed. R. Radzik, Lublin, 2012.

Bocheński W., "Między ZSRR a 'łukaszyzmem'. Kształtowanie się systemu społeczno-politycznego Białorusi w latach 1991-1994”, in: Zblizanie się Wschodu i Zachodu. Studia - analizy - rozpoznania, eds. P. Kraszewski, T. Miluski, T. Wallas, Poznań, 2002.

Browarek T., "Struktura narodowościowa i społeczna Białorusi”, in: Białoruś w stosunkach międzynarodowych, ed. I. Topolski, Lublin 2009. 
Dziarnowicz A., “'Poszukiwanie Ojczyzny’. Dyskurs na temat Wielkiego Księstwa Litewskiego we współczesnym społeczeństwie białoruskim”, in: Dialog kultur pamięci w regionie ULB, eds. A. Nikžentaitis, M. Kopczyński, Warszawa, 2014.

Foligowski P., Białoruś. Trudna niepodległość, Wrocław, 1999.

Frąckiewicz K., "Białoruska opozycja narodowa a problematyka 'odrodzenia’ polskości w BSRR-RB”, in: Polska mniejszość narodowa na Białorusi 1998-2009. Ocena minionego dwudziestolecia, red. Z.J. Winnicki, T. Gawin, Białystok, 2009.

Gawin T., Polskie odrodzenie na Białorusi 1988-2005, Białystok, 2010.

Gil A., W cieniu przeszłości. Stosunki polsko-ukraińskie i polsko-białoruskie - stan obecny i perspektywy, Lublin, 2010.

Głogowska H., Stosunki polsko-białoruskie w XX wieku. Od Imperium Rosyjskiego do Unii Europejskiej, Białystok, 2012.

Gumienik M., "Szermowały hasłami o jednolitym społeczeństwie”, Magazyn Polski, 1992, no. 3-4.

Hryckiewicz W., “Stan nauki i dydaktyki historii na Białorusi”, Przeglad Wschodni, 2 (1992/1993), no. 3(7).

Ioffe G., "Długotrwałe poszukiwanie białoruskiej tożsamości", in: Tożsamości zbiorowe Białorusinów, ed. R. Radzik, Lublin, 2012.

Kazakiević A., "Współczesna białoruska tożsamość historyczna”, in: Tożsamości zbiorowe Białorusinów, ed. R. Radzik, Lublin, 2012.

Krawcewicz A., Powstanie Wielkiego Księstwa Litewskiego, Białystok, 2003.

Krawcewicz A., "Wielkie Księstwo Litewskie - wizja litewsko-białoruska?”, in: Dialog kultur pamięci w regionie ULB, eds. A. Nikžentaitis, M. Kopczyński, Warszawa, 2014.

Kruczkowski T., Wasiuk H., "Historia Polski czasów WKL i Rzeczypospolitej w białoruskim czasopiśmiennictwie historycznym końca lat 80-tych - początku 90-tych XX w., in: Polsko-białoruskie związki językowe, literackie, historyczne i kulturowe. Materiały VI Międzynarodowej Konferencji Naukowej 'Droga ku wzajemności', Grodno-Nowogródek 25-27 IX 1998, ed. M. Kondratiuk, Grodno, 1999.

Lastoŭski A., "The Genealogy of National Statehood in the Historical Memory of Belarusians", in: Revolt in the Name of Freedom. Forgotten Belarusian Gene?, eds. P. Rudkoŭski, K. Kolb, Warsaw, 2013.

Łaniewski A., "O czym pamięta Białoruś? Katalog białoruskiej pamięci”, in: Pamięć imperiów $w$ Europie Wschodniej. Teoretyczne konteksty i porównania, eds. A. Nowak, M. Wojnar, Kraków, 2015.

Łatyszonek O., Mironowicz E., Historia Białorusi, Białystok [n.d.].

Mackiewicz T., "Powrót Białorusi do europejskiej przestrzeni kulturowej. Rola edukacji”, in: Raport o stanie kultury niezależnej i NGO w Białorusi, eds. T. Arcimowicz, A. Klinau, Lublin, 2011.

Mieczkowska N., "Stulecie białoruskiego odrodzenia narodowego. Główne wydarzenia i trendy w historii samoświadomości językowej i sytuacji językowej na Białorusi”, in: Tożsamości zbiorowe Białorusinów, ed. R. Radzik, Lublin, 2012.

Milewski J.J., "Polsko-białoruska komisja do spraw podręczników historii”, Białoruskie Zeszyty Historyczne, 1994, no. 2, p. 130.

Milewski J.J., "Polsko-białoruskie komisje podręcznikowe”, Zeszyty Historyczne, 1998, no. 123.

Mironowicz E., Białoruś, Warszawa, 1999.

Nowikow S., "Historiografia współczesnej Białorusi o Holocauście”, in: Świat niepożegnany. Żydzi na dawnych ziemiach wschodnich Rzeczypospolitej w XVIII-XX wieku, ed. K. Jasiewicz, Warszawa, 2005.

Owsiannik S., Striełkowa J., Władza a społeczeństwo. Białoruś 1991-1998, Warszawa, 1998, p. 69. 
Pawelski S., "Wesoły - smutny kraj. Białoruś pod rządami Aleksandra Łukaszenki", in: Zbliżanie się Wschodu i Zachodu. Studia - analizy - rozpoznania, eds. P. Kraszewski, T. Miluski, T. Wallas, Poznań, 2002.

Poczobut A., System Białoruś, Gliwice, 2012.

Radzik R., Białorusini - między Wschodem a Zachodem, Lublin, 2012.

Radzik R., "Formowanie się nowoczesnej Białoruskości w XX stuleciu”, in: Białoruś w XX stuleciu $w$ kręgu kultury i polityki, ed. D. Michaluk, Toruń, 2007.

Riabczuk M., "Wschodniosłowiańska 'umma' a problem emancypacji. O 'słabej' tożsamości Ukraińców i Białorusinów”, in: Tożsamości zbiorowe Białorusinów, ed. R. Radzik, Lublin, 2012.

Rudkouski P., Białoruska idea narodowa w XXI wieku, Lublin, 2008.

Sahanowicz H., "Losy białoruskiej historiografii: od sowietyzacji do zachodniorusizmu nowego typu", Studia Białorutenistyczne, 2009, no. 3.

Sahanowicz H., "Wojna z białoruską historią", in: Tematy polsko-białoruskie. Historia. Literatura. Edukacja, ed. R. Traba, Olsztyn, 2003.

Smalanczuk A., "Problemy rozwoju białoruskiej historiografii postsowieckiej albo nauka pod “jarzmem sowieckości”, Studia Białorutenistyczne, 2011, no. 5.

Szuplak P.A., "Problemy edukacji historycznej w szkołach wyższych Republiki Białoruś”, in: Polska-Białoruś 1918-1945, ed. W. Balcerak, Warszawa, 1994.

Śleszyński W., Kresy Wschodnie czyli Białoruś Zachodnia. Historia, wspótczesność, pamięć, Łomianki, 2013.

Temper E., "Mity założycielskie Białorusi. Wielkie Księstwo Litewskie kontra Republika Partyzantów", in: Dialog kultur pamięci w regionie ULB, eds. A. Nikžentaitis, M. Kopczyński, Warszawa, 2014.

Winnicki Z.J., Ideologia państwowa Republiki Białoruś - teoria i praktyka projektu. Analiza politologiczna, Wrocław, 2013.

Winnicki Z.J., Tematy białorusko-polskie. Antologia, Wrocław, 2010.

Winnicki Z.J., Współczesna doktryna i historiografia białoruska (po roku 1989) wobec Polski i polskości, Wrocław, 2003.

Wołkonowski J., "Polityka historyczna Litwy w latach 1990-2010. Aspekt polski”, in: Wspólne czy osobne? Miejsca pamięci narodów Europy Wschodniej, ed. W. Śleszyński, BiałystokKraków, 2011.

“13 февраля одному из самых ярких политических деятелей Беларуси Петру Мироновичу Машерову исполнилось бы 76 лет", Советская Белоруссия, 12 February 1994, no. 32-33.

100 пытанняу і адказаў з гісторыі Беларусі, eds. І. Саверчанка, 3. Санько, Мінск, 1994.

Аўтар, 3 жыция Антона Луцкевіча, Літаратура і мастацтва, 18 January 1991.

“Будуй жа сваё жыццё, беларус!”, Звязда, 20 January 1993, no 13.

Багадзя М., “Гальшанскі замак”, Беларусь, 1991, no. 2.

Багадзяж М., “Мяцежны гетман”, Звязда, 23 January 1993, no. 14.

Баранова М., Загорульский Э., Павлова Н., История БССР. Учебник для 8-9 классов средней школы, Минск, 1991.

“Белорусское барокко”, Советская Белоруссия, 11 June 1994, no. 121-122.

Біч М., “Аб нацыянальнай каниэпиый гісторыі і гістарычнай адукацыь ў Рэспубліцы Беларусь", Беларускі гістарычны часопіс, 1993, no. 1.

Божанов В., “Если память короткая. Октябрь 1917-го. Август 1991-го. Насколько относительна и правомерна аналогия?”, Беларуская думка, 1991, nо. 6. Бондаренко В., “Ты говоришь дело, но не по делу", Рэспубліка, 11 Мау 1992, nо. 86.

Бордюгов Г., Козлов В., История и конъюнктура. Субъективные заметки об истории советского общества, Москва, 1992. 
“Ведаць гісторыю - бачыць будучыню”, Беларуская мінуўшчына, 1993, no. 1.

Врублевский А., Протько Т., Из истории репрессий. Против белорусского крестьянства 1929-1934 г2., Минск, 1992.

Гриб М., Кебич В., “Участникам освобождения Беларуси от немецко-фашистских захватчиков”, Советская Белоруссия, 2 July 1994, no. 138.

Гришан И., “Ледокол в торосах лжи”, Советская Белоруссия, 22 June 1994, no. 131.

Гришан И., "Обретение Родины. 55 лет назад произошло воссоединение белорусских земель”, Советская Белоруссия, 17 September 1994, no. 198-199.

Доўнар-Запольскі М., Гісторыя Беларусі, Мінск, 1994.

Ермаловіч М., Старажытная Беларусъ. Віленскі перыяд, Мінск, 1994.

Ермаловіч М., Па слядах аднаго мібба, Менск, 1991.

Ермолович В., Жумарь С., Огнём и мечом. Хроника польского националистического подполья в Белоруссии (1939-1953 г2.), Минск, 1994.

Запруднік Я., Беларусь на гістарычных скрыжаваннях, Мінск, 1996.

Ігнатоўскі У., Кароткі нарыс гісторыі Беларусі, Мінск, 1992.

Казакевіч А., “Канцэпцыі (ідэі) беларускай нацыі ў перыяд незалежнасці 1990-2009”, Палітычная сфера, 2010, nо. 14.

Казбярук У., “Паміж молатам а кавадлам, або Крок наперад, два крокі назад”, Літаратура i мастацтва, 8 March 1991.

Касцюк М., “За волю, роўнасць, незалежнасць. Да 200-годдзя паўстання ў Польшчы, на Беларусі і ў Літве”, Беларуская думка, 1994, nо. 7.

Касцюк М., Ігнаценка І., Вышынскі У. (і інш.), Нарысы гісторыі Беларусі, ч. 2, Мінск, 1995.

Кебич В., “Дорогие ветераны Великой Отечественной войны!”, Советская Белоруссия, 7 May 1994, no. 93-94.

Ковалев М., “Чужие на своей земле”, Советская Белоруссия, 1 October 1994, no. 235.

Колесников В., “Путь к тирании. Страницы биографии Гитлера и Сталина”, Рэспубліка, 23 June 1992, no. 117.

Кравцевич А., Смоленчук А., Токть С., Белорусы: нация Пограничья, Вильнюс, 2011.

Крэнь I., "Праблемы Арміі Краёвай у беларускай гістарыяграфіi (сярэдзіна 80-х - 90-я гады)", in: Polsko-białoruskie związki językowe, literackie, historyczne i kulturowe. Materiały VI Międzynarodowej Konferencji Naukowej 'Droga ku wzajemności', Grodno-Nowogródek 25-27 IX 1998, ed. M. Kondratiuk, Grodno, 1999.

Кушнер В., “Гістарычная адукацыя і палітыка”, Беларускі гістарычны часопіс, 1996, nо 4. Ластовский А., “Советское прошлое и беларусская культурная память”, in: O десоветuзачии. Беларусь, начало ХХІ века. Материаль семинара-конферениии, г. Шилуте (Литва), 20-24 августа 2007 г., Минск, 2008.

Ластовский А., Специфика исторической памяти в Беларуси: между советским прошльмм и национальной перспективой, http://www.polit.ru/article/2010/07/19/belorus/.

Ластоўскі А., Гістарычная памяць у Беларусі: адметнасці і праблемь, http://old. belcollegium.org/lekcyji/litaratura/lastouski_01.htm.

Ластоўскі А., “Улада і стварэнне гісторыі ў Беларусі: нататкі да канцэптуалізацыі”, in: Беларусь в европейском контексте: актуальные дискуссии о нациостроительстве, eds. О. Шпарага, А. Смоленчук, Вильню,с 2014.

“Ленина выселили из Кремля”, Рэспубліка, 9 September 1994, no. 175.

Лінднер Р., “Нацыянальныя і 'прыдворныя’ гісторыкі ‘лукашэнкаўскай’ Беларусі”, Гістарычны Альманах, 4 (2001).

Лінднэр Р., Гісторыкі і ўлада. Нацыятворчы праиэс і гістарычная палітыка ў Беларусі XIX-XX cm., Мінск, 2005.

Марціновіч А., “Памятае не толькі Вольса..., Літаратура і мастацътва, 11 October 1991. 
Медведев Р., Александр Лукашенко. Контуры белорусской модели, Москва, 2010.

Минич А.П., Развитие исторической науки Республики Беларусь в 90-е г2. ХХ в. (формирование новых тенденций), (a self-report study), Гродно, 2009.

Михайлов С., “Белая Русь в марте семнадцатого”, Рэспубліка, 12 March 1992, no. 49.

“Мужыкі і бабы, або аб тым, як з дапамогаю кулака выпрамлялася партыйная лінія ў сялянскім пытанні”, Беларусь, 1991, по. 7.

Островская Т., "Генеалогия исторической памяти Белорусов в контексте образовательных практик”, Исследование. Bielarusian Institute for Strategic Studies, 20 October 2010.

“От великой победы к стабильности и согласию. Выступление Председателя Совета Министров Републики Беларусь В.Ф. Кевича на торжественном собрании, посвященном 50-летию освобождения Беларуси от немецко-фашистских захватчиков”, Рэспубліка, 30 June 1994, по. 125.

Петриков П.Т., Очерки новейщей историографии Беларуси (1990-е - начало 2000-х годов), Минск, 2007.

Прэзідыум Вярхоўнага Савета Рэспублікі Беларусь, “Са святам вас, суайчыннікі, з Днём незалежнасці!”, Рэспубліка, 26 July 1994, no. 144.

Раманчук П., “Залаты час Льва Сапеги”, Рэспубліка, 25 July 1992, no. 179.

Рашэтнікаў С., Бенькоўскі В., “Прагнастычны праект. Беларусь - Польшча", Беларусь, 1993, no. 2.

Саганович Г., “Историческая политика в постсоветской Беларуси”, Русский вопрос, 2009, no. 2, http://www.russkiivopros.com/print.php?id=278.

Сагановіч Г., “Змена міфаў беларускай гісторыі як змена палітычных эпох”, in: Беларусь на авансиэне Еўразіі. Паміж Масквой і Кіевам, пад рэд. К. Колб, Варшава, 2014.

Саламонаў А., “Якой ты была, Беларусь мая? Ці яшчэ раз пра дзяржаўныя межы”, Беларусь, 1991, no. 9.

Сідарэвіч А., “3 жыцця Антона Луцкевіча. Артыкул другі. Астрожныя запісы”, Літараmура і мастацтвва, 25 January 1991.

Смалянчук А., “Савецкасиь беларускай постсавецкай гістарыяграфіi”, in: Sprawy trudne. Z dziejów stosunków polsko-białoruskich w latach 1918-1945. Geneza, konteksty, konsekwencje, Mińsk, 2013.

Смалянчук А., “Беларуская постсавецкая гістарыяграфія: паміж рэсаветызацыяй і новай карпаратыўнай этыкай”, Arche, 2013, no. 2.

Смалянчук А., “Верасень 1939 г. у савецкай і беларускай гістарыяграфіi”, Гістарычны Альманах, 3 (2000).

Смалянчук А., “Радкевіч versus Каліноўскі?”, Homo Historicus, 2008.

Снапковский В., “Историческая политика в Беларуси в период перестройки и парламентской республики (1985-1994 гг.)”, Труды факультета международных отношений. Научный сборник, 2014, по. 5.

Стэльмак М., “Адгукніцеся, беларускія сэрцы! Аб сённяшнім і мінулым напярэдадні 100-гадовага юбілею Браніслава Тарашкевіча”, Рэспубліка, 18 January 1992, no. 11.

Суверенная Беларусь. Иллюстрированная история государства 1991-2008, Минск, 2008.

Ткачоў М., Марчук Г., “Князь Давыдко”, Рэспубліка, 14 July 1992, no. 132.

Тохта-Ходжаева Р., “Мы не манкурты? Так кто же мы?”, Рэспубліка, 20 June 1992, no. 116.

“Усё вяртаецца на кругі свае”, Беларусь, 1993, nо. 6.

Філякоў У., “Падымайся з нізін, сакаліна сям'я... Пра станаўленне нацыянальнай самасвядомасці беларусаў”, Беларуская думка, 1993, по. 2.

Хацкевич А., “Сентябрь 1939 года...”, Рэспубліка, 17 September 1992, no. 178.

Цьвікевіч А., “Западно-руссизм”. Нарысы з гісторыі грамадзкай мысьлі на Беларусі у ХІХ i начатку XX в., Менск, 1993. 
Шаталава В., “Нацыянальная ідэя на старонках беларускай прэсы 1991-1994 гг., in: Białoruś w XX stuleciu w kręgu kultury i polityki, ed. D. Michaluk, Toruń, 2007.

Шушкевіч С., “Калектыву 'Беларускага гістарычнага часопіса”, Беларускі гістарычны yaconic, 1993, no. 1.

Якаўлева Т., “Беларуская ідэя і Вялікае Княства Літоўскае”, Беларуская думка, 1992, no. 10.

\section{Internet site}

www.belpost.by/eng/stamps/stamp-catalogue/1993/

Wojciech Śleszyński, dr hab., associate professor of the University of Białystok (currently Vice-Rector for education of the said university), director of the Sybir Memorial Museum. His research focuses primarily on the history of the north-east regions of inter-war Poland. His activities include publishing source material preserved in a number of archival collections kept in Belarus, Lithuania and Russia as well as writing popular articles on the history of the modern-day borderland regions of Poland, Lithuania and Belarus. He has published over 120 research works, including ten books (wsleszynski@poczta.onet.pl). 